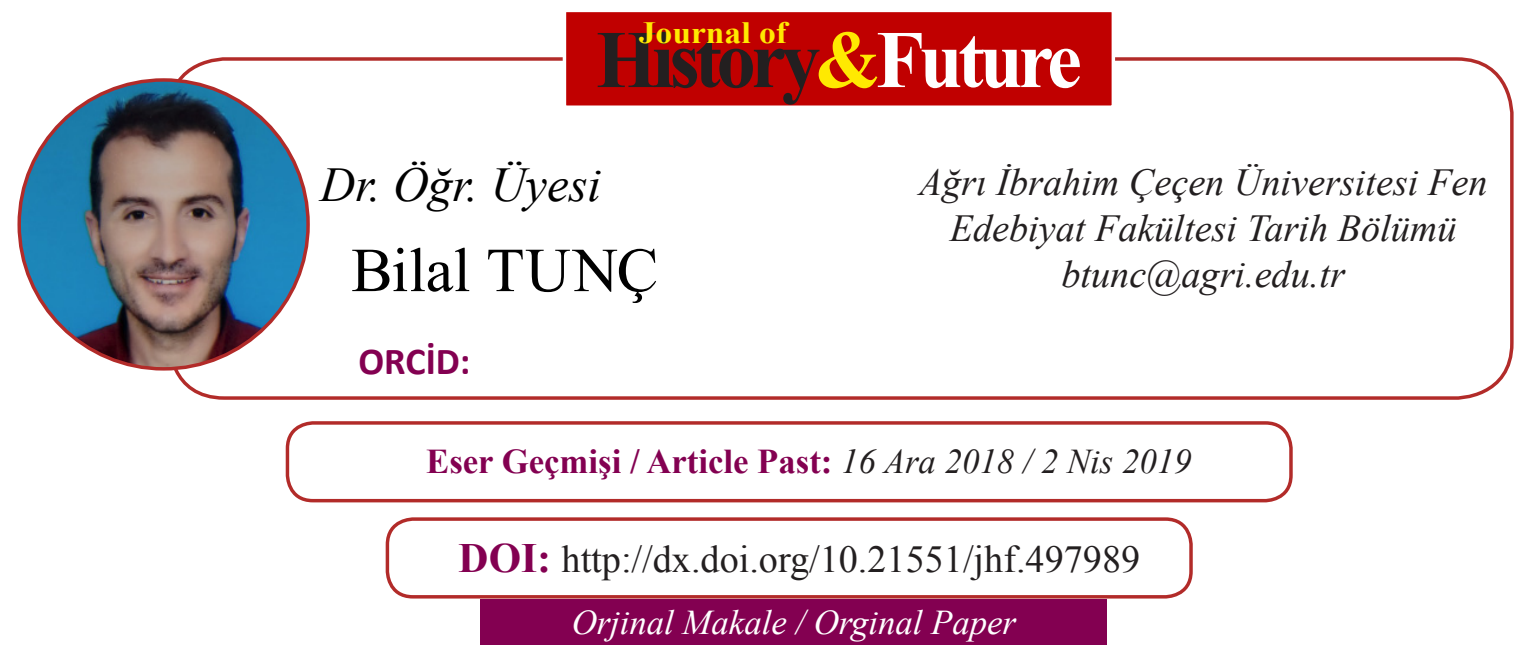

\title{
27 Mayıs Askeri Darbesinin Vilayetlerdeki Yansımaları: Bitlis Örneği
}

\author{
The Effect of 27 May Military Coup in Cities: Example of Bitlis
}

\section{$\ddot{\mathbf{O z}}$}

Malum olduğu üzere, Türkiye'de ordu tarafından 27 Mayıs 1960'ta bir askeri darbe gerçekleştirilen askeri darbe neticesinde Demokrat Parti'nin (DP) iktidarına son verilmiş ve demokrasiye zarar verilmiştir. Bu durum, aynı zamanda Türkiye'de bir darbe sürecini de başlatmıştır. Bu kapsamda, 27 Mayıs Darbesi'nin Bitlis’te nasıl bir etki bıraktığını değerlendirmek için DP Dönemi'nde Bitlis ilinde basılan yerel gazetelerden Yeşil Bitlis, Dideban, Tasviri Efkâr ve Yeni Dideban gazeteleri değerlendirilecektir.

Bilindiği üzere 27 Mayıs 1960 Askeri Darbesinin ülke genelinde ciddi bir tepkiyle karşılanmiş ve demokrasi açısından kötü sonuçlar doğurmuştur. Bu çalışmada bahsi geçen askeri darbenin Bitlis vilâyetinde nasıl karşılandığı ve Bitlis halkının bu darbeye ne gibi tepkiler gösterdiği ayrıntılı bir biçimde ele alınmaktadır. Söz konusu etkilerin objektif bir biçimde değerlendirilebilmesi için Türkiye'de tek partili hayatın sona erip çok partili yaşama geçilme aşaması, DP'nin iktidara gelmesi ve ülkede darbeye yol açan koşullar neden sonuç ilişkisi ve tarihsel süreç bağlamında ele alınmaktadır. Bu bağlamda, Yeşil Bitlis, Dideban, Tasviri Efkâr ve Yeni Dideban gazetelerinin haberleri detaylı bir biçimde incelenerek 27 Mayıs 1960 Darbesi neticesinde mezkûr gazetelerin nasıl bir tutum takındığı ve kamuoyu oluşturmadaki gücü araştırılmaktadır. Bu eser, başta resmi gazete verileri olmak üzere; araştırma ve inceleme eserlerinden yararlanılarak oluşturulmuştur.

Anahtar Kelimeler: 27 Mayıs 1960, Darbe, Basın, Gazete, Bitlis.

ATIF: TUNÇ Bilal, “27 Mayıs Askeri Darbesinin Vilayetlerdeki Yansımaları: Bitlis Örneği” Tarih : ve Gelecek Dergisi, 5/1 (Nisan-2019), s. (38-51) 


\begin{abstract}
As it is known, a military coup was carried out by the army on 27 May 1960 in our country and with the removal of the Democratic Party, which came to power with the free votes of the people, democracy was hit hard. This situation also launched a coup of process in Turkey.In this context, in order to assess how the May 27 coup d'etat affected Bitlis, local newspapers published in Bitlis during the Democratic Party period have been benefited. This newspapers are: Yesl Bitlis, Dideban, Tasviri Efkâr and Yeni Dideban.

In this study while the impact of the May 27 Military Coup in the country has been taken into account, the echoes of the effect of the coup in Bitlis are analyzed at the same time. In order to evaluate and analyze these effects in an objective manner; Turkey's multi-party transittion, developments in the Democratic Party's power and military intervention are handled in terms of historical development. In the context of these data, thoroughly examining the news of journalists of the Yesil Bitlis, Dideban, Tasviri Efkar and Yeni Dideban; it is being investigated that what kind of attitude was taken by the mentioned newspapers in the face of the May 27, 1960 Military Intervention and power of public opinion. This piece shall be created by utilizing various research and examination works, primarily local newspapers veri.
\end{abstract}

Key words: 27 May 1960, Impact, Press, Newspaper, Bitlis.

\title{
GİRIȘ
}

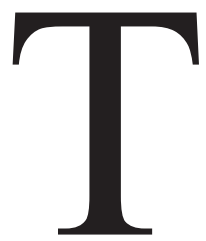

ürkiye'de DP'nin iktidara geliş sürecinin tam olarak anlaşılması ve Tek Parti iktidarına nasıl son verildiğinin açıklanabilmesi için Türk siyasal hayatında çok partili hayata geçiş süreci ayrıntılı bir biçimde ele alınmalıdır. Bu bağlamda Cumhuriyet'in ilk dönemleri ele alındığında, bu devirde çok partili hayata geçiş denemelerinin olduğu görülmektedir. CHP'den sonra kurulan Terakkiperver Cumhuriyet Fırkası(TCF)bu amaçla açılmıştır. ${ }^{1}$ Daha sonra da Serbest Cumhuriyet Fırkası (SCF) kurulmuştur. ${ }^{2}$ TCF ve SCF bu dönemde kurulup, daha sonra kapatılan partilerdir. 1924 yılında kurulan TCF'nin ömrü uzun olmamış ve parti, 5 Haziran 1925 'te kapatılmıştır. ${ }^{3}$

Türk siyasi tarihinde çok fazla uzun süreli varlık sürdüremeyen TCF'den sonra 1930 yılında yeni bir parti daha kurulmuştur. Çok partili hayata geçişte ikinci bir aşama olan bu partinin adı SCF'dir. ${ }^{4} \mathrm{Bu}$ tarihlerde CHP dışında varlık göstermeye başlayan yeni partiyle beraber ülkedeki siyasal sorunların giderilebileceği ve ülkede çok acil olarak yapılması gereken mali ve ekonomik reformların kolay olarak yürürlüğe konulacağı düşünülmekteydi. Bilhassa yeni parti SCF'nin mutedil olan siyasi yaklaşımının Türkiye'nin Avrupa ülkeleri nezdindeki algısını ciddi bir biçimde değiştirerek bu ülkelerin Türkiye'ye karşı bakışını olumlu bir hale getireceği sanılıyordu. Dönem iti-

1 Tevfik Çavdar, Türkiye'nin Demokrasi Tarihi (1839-1950), 3. Bask1, İstanbul: İmge Kitabevi, 2013, s.263.

2 Bernard Lewis, Modern Türkiye’nin Doğuşu, 5. Baskı, (Çev. Prof. Dr. Metin Kıratlı), Ankara: Türk Tarih Kurumu Yayınları, 1993, s.278-279.

3 Cemalettin Taşkıran, Atatürk Döneminde Demokrasi Denemeleri (1925-1930), Ankara Üniversitesi Türk İnkılâp Enstitüsü Atatürk Yolu Dergisi, 4/14 (1994), s.259-260.

4 Erik Jan Zürcher, Modernleşen Türkiye’nin Tarihi, (Çev. Yasemin Saner Gönen), 7. Baskı, İstanbul: İletişim Yayınları, 2000, s.261. 
barıyla Türkiye'de tek partinin yöneticileri, halkın sorunlarından son derece uzaktılar ve bu durum da yeni kurulan partilerin halk tarafından ilgiyle karşılanmalarına ortam hazırlamaktaydı. Bundan dolayı, Serbest Fırkanın çağrıları ve söylemleri halk arasında ciddi destek görmüştür. ${ }^{5}$ Netice itibarıla yeni bir parti olarak kurulan ve gerçekten de halk arasında destek gören SCF, 17 Kasım 1930 tarihinde kendini feshetmiştir. Söz konusu partinin kendisini feshetmesiyle beraber Erken Cumhuriyet Dönemi çok partili hayata geçiş denemeleri nihayet bulmuştur. ${ }^{6}$

Her iki partinin kapatılmasıyla birlikte Türkiye'de 1946 yılına kadar tek partili yaşam süreci yeniden egemen olmuştur. Bu dönemlerde yeni kurulan devletin siyasi, sosyal, ekonomik vb. sorunlardan dolayı henüz çok partili hayata hazır olmadığını ortaya çıkmaktadır. Bu nedenle 1924 ve 1930 yıllarında kurulan iki önemli firka kapatılmak zorunda bırakılmıştır. Esasında bu siyasal hadiseler, inkılâpçı Mustafa Kemal'in kafasında tasarlanan çağdaşlaşma amacının bir uygulaması veya denemesi olarak değerlendirilebilir.?

Bu makalenin konusu genel olarak 27 Mayıs Askeri Darbesi'nin Bitlis genelinde ne gibi bir etki bıraktığıdır. Yöntem olarak Bitlis basını ve konuyla alakalı olarak kaynak eserler etraflıca incelenmiştir. Bu bağlamda, başta Yeşil Bitlis, Dideban, Tasviri Efkâr ve Yeni Dideban gazeteleri olmak üzere konuyla alakalı literatür taraması yapılmış ve konu derinlemesine irdelenmiştir.

\section{Tek Partili Hayattan Çok Partili Hayata Geçiş Sürecinde Siyasal Partilerin Bitlis’teki Teşkilatlanma Süreçleri}

Cumhuriyet tarihinin ilk siyasi partisi olan CHP ile Türkiye'de çok partili hayatı başlatan DP'nin Bitlis vilâyetinde teşkilatlandıkları ve burada il ve ilçe teşkilatlarını kurdukları görülmektedir. Bu bağlamda CHP İl Başkanlığı 1944 yılında teşkilatını kurmuş ve çalışmalarına başlamıştır. $\mathrm{Bu}$ bağlamda, CHP Bitlis İl Başkanlığı'nın teşkilatı ve başkanları ile yedek azalar şu kişilerden oluşmaktayd18:
a) Arif Özdemir: Reis (Vilâyet daimi encümen azası)
b) Cemil Okumuş: Kâtip (Tüccar)
c) Ziya Geboloğlu: Üye (Halkevi reisi ve avukat)
d) Mehmet Zülfikaroğlu: Üye (Tüccar)
e) Muhittin Barut: Üye (Tüccar)
Yedek Üyeler;
a) Yakup Sabri Bilgitay (Avukat)
b) Kasım Kake (Tüccar)
c) Fevzi Selahattin Doğru (Terzi)
d) Zeynettin Eren ( Emekli memur) Bilimler Araştırmaları Dergisi, 2010 1(2), s.71.

7

8

Feroz Ahmad, Modern Türkiye ’nin Oluşumu, 11. Baskı, Çev. Yavuz Alogan, İstanbul: Kaynak Yayınları, 2012 , s.80.

Barış Ertem, Siyasal Bir Muhalefet Denemesi Olarak Serbest Cumhuriyet Fırkası, ODTÜ Sosyal Bilimler Enstitüsü Sosyal

Cemalettin Taşkıran, Atatürk Döneminde Demokrasi Denemeleri (1925-1930), s.265

Şükran Gündoğdu, "Bitlis ve Bitlis Halkevi”, (Yayınlanmamış Yüksek Lisans Tezi), Yüzüncü Yıl Van Üniversitesi Sosyal Bilimler Enstitüsü, Van, 2013, s.47. 
e) Tahsin Oto (Tüccar)

CHP’nin Doğu Anadolu Bölgesi’nin önemli vilâyetlerinden başta Bitlis başta olmak üzere çoğu yerde teşkilatlarını neden geç kurdukları CHP müfettiş raporlarına çok bir biçimde yansıtmaktadır. Raporlara göre, teşkilatlanmanın ve örgütlerin çok geç olmasının temel sebeplerinden birisi barınma ve maddi sorunların ön planda gelmektedir. Ayrıca buralarda Halkevleri ve Halkodaları olduğu için, bu kurumlar bir yerde parti teşkilatı gibi çalışmışlardır. Bu nedenlerden dolayı parti 1923 yılında kurulmasına rağmen CHP İl Başkanlığı ancak 1944 yılında Bitlis İl Başkanlığını kurabilmiştir'.

CHP Bitlis İl Başkanlığı ilk kurulduğunda 5 asil ve 5 de yedek olmak üzere 10 kişiden oluşmaktaydı. Ancak bu durumun 1945 yılında değiştiği ve üye sayısının hem yedeklerde hem de asillerde ikişer kişi arttırıldığı ve üye sayısının 14'e çıkarıldığı görülmektedir. Bu kapsamda asil gruba Vehbi Öztekin ve Aziz Menteş adlı kişiler dâhil edilmişken; yedekler grubuna ise Şaban Kaya ve Ekrem Erdör eklenmiştir. Böylece CHP İl Başkanlığı Bitlis genelinde son derece etkili bir siyasi yap1 durumuna getirilmiştir ${ }^{10}$.

DP kurulduktan sonra 1946 yılında ülke genelinde kısa bir süre içerisinde il ve ilçe teşkilatlarını oluşturmuş ve siyasi faaliyetlerine de başlamıştır ${ }^{11}$. Daha sonraki süreçte ise DP Bitlis İl Başkanlığı kurulmuştur. DP İl Başkanlığının en önemli iki üyesi Ziya Şerifhan ve Rıza Geboğlu isimli şahıslar olmuştur. Adı geçen iki kişi, 14 Mayıs 1950 tarihinde yapılan Milletvekili Genel Seçimlerinde Bitlis’ten DP adayı olarak seçimlere katılmışlardır.

\section{DP'nin İktidara Gelmesi ve Bitlis’teki Milletvekili Genel Seçimleri}

DP, 14 Mayıs 1950'de yapılan seçimlerle 27 yıllık CHP iktidarına son vermiş ve tek başına iktidar olmayı başarmıştır. Daha sonra da yapılan 1954 ve 1957 genel seçimlerini de kazanmış ve on yıl boyunca ülkeyi tek başına yönetmiştir. Bu sürece Türk siyasal hayatında DP devri denilmektedir.

DP'nin Bitlis'ten aday gösterdiği ve seçimlere katıldığı 1950 Milletvekili Genel Seçimlerindeki adayları Ziya Şerifhan ve Rıza Geboğlu isimli şahıslardır ${ }^{12}$. Ancak bu dönemde yapılan seçimlerde DP'li adaylar değil de CHP'nin adayları olan Nusrettin Barut, Ahmet Muhtar Talati Ertan ve Selahattin İnan isimli şahıslar seçimleri kazanarak milletvekili olmayı başarmışlardır ${ }^{13}$.

1950 seçimlerinden sonra 1954 yılında Milletvekili Genel Seçimleri yapılmıştır. 1950’de iktidara gelen DP, yeni seçimler için kampanyasını dört yıllık hizmetleri ve çalışmaları üzerine oturtmuştur. DP, dört yıllık çalışmalarını temel alarak özellikle köylere yapılan yatırımları anlatarak insanlardan yeniden oy istemiştir. DP'nin son derece etkin bir seçim çalışması yaptığı dönemde CHP'nin seçim propagandaları son derece olumsuz geçmiştir. En nihayetinde 1954 yılında yapılan Milletvekili Genel Seçimlerinde DP, büyük bir başarı elde ederek meclisteki mebusların \% 90'nını

9 Murat Turan, “Cumhuriyet Halk Partisi’nin Doğu Örgütlenmesi”, (Yayınlanmamış Yüksek Lisans Tezi), Dokuz Eylül Üniversitesi Sosyal Bilimler Enstitüsü, İzmir, 2010, s.147-148.

10 Şükran Gündoğdu, "Bitlis ve Bitlis Halkevi”, s.47-48.

11 Enis Şahin ve Bilal Tunç, Demokrat Parti'nin Kuruluş Süreci ve DP-CHP Siyasi Mücadelesi (1945-1947), Sosyal ve Kültürel Araştırmalar Dergisi, $1 / 2$ (2015), s.37.

12 Şükran Gündoğdu, "Bitlis ve Bitlis Halkevi", s.90.

13 Kazım Öztürk, Türk Parlamento Tarihi, TBMM-IX. Dönem (1950-1954), VII. Cilt, Ankara: Türkiye Büyük Millet Meclisi Yayınlar1, 1999, s.163-167. 
almayı başarmıştır ${ }^{14}$.

1954 seçimleri için Bitlis’te CHP ve DP adayları arasında ciddi bir yarış olmuş ve partililer, seçim propagandalarını yürütmüşlerdir. Her ne kadar 1950 seçimlerini CHP kazanmış olsa da 1957 seçimlerini DP kazanmış ve açık oy farkla bütün milletvekillerini tek başına çıkarmıştır. Buna göre, DP \% 62,9 oranında oy almış iken CHP sadece \% 21 oy almıştır. DP'li Bitlis Milletvekili adayları olan Nusrettin Barut ve Selahattin İnan isimli şahıslar seçimleri kazanan kişilerdirr' ${ }^{15}$.

1950 ve 1954 seçimlerini kazanan DP, 1957’ye geldiğinde biraz tepki çekmeye başlamıştı. Ancak DP açısından mevcut olan olumsuzluklara rağmen yine de avantajlı durumda bulunmaktayd. Örneğin iktidar partisi enflasyonla mücadele etmiş, çiftçilerin borçlarını ödemeye çalışmış ve kırsal kesimdeki seçmenlere birtakım yatırımlar yapmıştı. Bilhassa DP'nin okul ve cami yapımları için fonlar ayırması ve bunu da halka anlatması onu ayrıcalıklı bir duruma getirmiş̧ti. Bu arada DP içinde de birtakım sıkıntılar vardı ve bu da seçim çalışmalarını etkilemekteydi. Buna rağmen 1957 yılında yapılan milletvekili genel seçimlerini DP yeniden kazanmış ve meclisteki çoğunluğu sağlamışt1 ${ }^{16}$.

1957 yılı Milletvekili Genel Seçimlerinde Bitlis vilâyetinde birtakım değişimlerin ve farklılıkların olduğu göze çarpmaktadır. Örneğin DP 1954'teki oylarını \% 62'den \% 60'a düşürmüş, CHP ise oylarını \% 21 'den \% 37,2'ye çıkarmıştır. Buna rağmen dönemin seçim kanunundan dolayı Bitlis'teki bütün milletvekillerini DP tek başına çıkarmıştır. 1957 yılında DP'den seçilen milletvekilleri Nusrettin Barut, Selahattin İnan ve Rıfat Bingöl isimli şahıslardır ${ }^{17}$.

\section{27 Mayıs 1960 Askeri Darbesi}

Türk siyasal hayatında DP'nin iktidarda olduğu dönemde 27 Mayıs 1960'ta yapılan bir asb keri darbe neticesinde halkın oylarıyla yani ulusal egemenlik ilkesi doğrultusunda iktidara gelen bir partinin, yani DP'nin, varlığına son verilmiştir. Malum olduğu üzere; 27 Mayıs askeri darbesi, ordu içindeki küçük bir grup tarafından gerçekleştirilmiş olup; ordudaki emir komuta zinciri içinde yapılmamıştır. Bu durum, ordu içinde büyük bir grubun da bu darbeyi desteklemediğini açıç̧a göstermektedir. Şevket Süreyya Aydemir'in verdiği bilgilere göre; 27 Mayıs askeri darbesinin asıl lideri ve darbecilerin teşkilatlanmasını sağlayan asıl kişi Tümgeneral Cemal Madanoğlu'dur. Ancak Cemal Madanoğlu'nun rütbesinin orgenerallikten küçük olması dolayısıyla emir komuta zincirinin bozulacağı tehlikesi belirmiş ve bu nedenle darbecilerin başına Orgeneral Cemal Gürsel getirilmesi sağlanmıştır. ${ }^{18}$

27 Mayıs Askeri Darbesi, içinde birtakım gariplikleri barındıran bir hadisedir. Bunlardan birisi, ordu içinde söz konusu darbeyi istemeyenlerin çoğunlukta olmasıdır. Ayrıca harekete s1rasında bu darbeye karşı ciddi tepkilerin varlığ 1 da bunlardan birisidir. Örneğin darbeye karşı direnişi engellemek amacıyla, ilk olarak Tümgeneral Selahattin Kaplan komutasındaki 28. Tümen,

14 İlyas Topçu ve Nebahat Oran Aslan, Kars'ta 1950-1954-1957 Milletvekili Seçimleri ve Demokrat Parti, Türkiyat Araştırmaları Enstitüsü Dergisi, 58 (2007), s.397.

15 Kazım Öztürk, Türk Parlamento Tarihi TBMM- X. Dönem (1954-1957), III. Cilt, Ankara: Türkiye Büyük Millet Meclisi Yayınlar1, 2010, s.130-131.

16 Sedef Bulut, Üçüncü Dönem Demokrat Parti İktidarı (1957-1960): Siyasi Baskılar ve Tahkikat Komisyonu, Akademik Baklş Dergisi, $2 / 4$ (2009), s.130.

17 Zühtü Arslan, Türk Parlamento Tarihi TBMM- XI. Dönem (1957-1960), III. Cilt, Ankara: Türkiye Büyük Millet Meclisi Yayınlar1, 2013, s.219-220.

18 Şevket Süreyya Aydemir, Menderes'in Dramı (1899-1960), Ankara: Remzi Kitabevi, 2016, s.456. 
Tuğgeneral Yusuf Demirdağ komutasındaki Zırhlı Eğitim Merkezi, Süvari Yarbay Reşit Çölok komutasındaki 43. Süvari Alayı, Binbaşı Hakkı Bozok komutasındaki Tank Taburu etkisiz hale getirilmiştir. İkincide ise, ordu evindeki subaylar teslim alınmıştır. Ancak burada çatışmalar çıkmış, Ankara 27 Mayıs'a bu seslerle uyanmıştır. ${ }^{19}$ Böylece bir darbenin olduğu anlaşılmış ve darbe ülke genelinde büyük bir şok etkisi yapmıştır.

27 Mayıs 1960 Askeri Darbesi ile Türkiye, yeni bir olayla yani darbe denilen hadiseyle tanışmış ve darbe gününde halkın daha önceden alışık olmadığı hadiseler yaşanmıştır. Bunlardan birisi, darbe sabahının ilk saatlerinde, Cumhurbaşkanı Celal Bayar, TBMM Başkanı Refik Koraltan ve İçişleri Bakanı Namık Gedik başta olmak üzere DP milletvekillerinin gözaltına alınarak Harp Okulu binasına götürülmesi ve ikincisi geriye kalan Adnan Menderes'in de Kütahya yolunda tutuklanarak Harp Okulu'na getirilmesidir. Adı geçen kişiler, devrin cumhurbaşkanı, başbakanı ve bakanı olan önemli aktörleridir. Bu durum, darbe sonrasında ülkedeki önemli yöneticilerin darbe sonucunda görevden alındıklarını açık bir biçimde ortaya çıkarmaktadır.

Darbe sabahı Cumhurbaşkanı Celal Bayar, kendisine yönelik istifa tekliflerini, "Seçimle geldim, ancak seçimle giderim” diyerek reddetmiştir. Celal Bayar'ın bu çıkışı üzerine Cemal Madanoğlu, yaptıkları darbeyi meşru bir zemine oturtmak için yeni bir planı yürürlüğe koymuş ve geçici bir anayasa hazırlatmıştır. Komisyonun başkanlığını Sıddık Sami Onar yapmıştır. ${ }^{20}$ Aralarında önemli Anayasa hukukçularının bulunan kişilerin hazırladığı geçici anayasa ile TBMM'ye ait tüm görev ve yetkiler darbeyi yapan Milli Birlik Komitesi'ne devredilmiştir. Hükümet, çalışmalarının gizli olacağı belirtilen Milli Birlik Komitesi’ne karşı sorumlu tutulmuştur. Böylece ülkenin yönetimi geçici bir süreliğine askeriyenin denetimine bırakılmıştır.

\section{27 Mayıs 1960 Asker Darbesinin Bitlis’teki İlk Yansımaları}

1950, 1954 ve 1957 yıllarında yapılan milletvekili genel seçimlerinin tamamında Bitlis ilinde birinci parti olan DP yönetimine karşı yapılan darbeye karşı Türkiye genelinde olduğu gibi Bitlis'te de hem olumlu hem de olumsuz eleştiriler olmuştur. Bitlis vilâyetinde darbenin nasıl karşılandiğ 1 vilâyetin gazeteleri olan Tasvir Efkâr, Dideban, Yeşil Bitlis ve Yeni Dideban'da bariz bir biçimde görülebilmektedir.

Yukarıda adı geçen gazetelerin DP devrindeki yayınlarına bakıldığında bunların çoğunlukla iktidar yanlısı bir yayın politikası takip ettikleri anlaşılmaktadır. Lakin 27 Mayıs Askeri Darbesi'nden sonra bu gazetelerin yazılarının içeriklerini değiştirdikleri ve darbeyi övücü yazılar kaleme aldıkları görülmektedir. Gazetelerin yayın politikalarında yaptıkları bu değişiklikler, dönem itibarıyla basın organlarının içinde bulundukları durumu göstermesi bakımından çarpıcıdır. Burada belirtilmek istenen şey şudur: Darbeden önce adı geçen makaleler, genel olarak DP politikalarını övücü yazılar kaleme almış iken; darbe sonrasında basın taraf değiştirmiş ve DP karşıtı yayınlar yapmıştır.

Bilindiği üzere Türkiye'de basın çok güçlüdür ve kamuoyu oluşturmada önemli bir güce sahiptir. Bilhassa, 27 Mayıs 1960 askeri darbesi sırasında da bu yönünü ortaya çıkaran basın organları darbe yanlısı bir tutum içinde bulunmuşlardır. Bu bağlamda, Bitlis gazeteleri olan Yeşil Bitlis, Dideban, Tasviri Efkâr ve Yeni Dideban da darbe karşısında tarafsız kalmamış ve orduyu

19 Ümit Özdağ, Menderes Döneminde Ordu-Siyaset İlişkileri ve 27 Mayıs İhtilali, İstanbul: Boyut Yayın Grubu, 2004, s.240241.

20 Yıldönümünde 27 Mayıs’1 Hatırlatmak, Türkiye Çalışmaları Grubu, Ankara: SDE Yayınları, 2010, s.10. 
övücü yazılar kaleme alarak onlar lehinde bir kamuoyu oluşturmaya çalıştıkları anlaşılmaktadır²1. $\mathrm{Bu}$ durum, makalede verilen örneklerle gösterilmeye çalışılmıştır.

26 Mayıs 1960 tarihine kadar Yeşil Bitlis, Dideban, Tasviri Efkâr ve Yeni Dideban gazetelerinin yazılarında Hükümet aleyhinde yazıların pek çıkmadığı, hatta Hükümeti öven yazıların olduğu görülmektedir. Örneğin darbeden hemen sonra adı geçen gazetelerin manşetlerine bakıldığında darbe konusunu geniş bir biçimde ele aldıkları görülmektedir. Örneğin Yeşil Bitlis ve Dideban gazetelerinde "Milli Birlik Komitesinin Tebliğleri"”, Türk Silahlı Kuvvetleri Başarılı Bir Biçimde Yönetime El Koymuştur”, "Kuvvet Kullanarak Değil Sulh İle” gibi başlıklar durumu özetlemektedir $^{22}$.

Başta Tasvir-i Efkâr ve Dideban olmak üzere Bitlis’teki gazetelerinin verdiği bilgilere göre, 27 Mayıs 1960 Askeri Darbesi'nin etkileri ülke genelinde olduğu gibi Bitlis’te de ciddi bir etki yapmıştır. Bitlis halkı darbenin olduğunu öncelikle radyodan daha sonra da Yeni Dideban gazetesinin “Türk Hava, Deniz ve Kara Silahlı Kuvvetleri Dün Gece Yarısından Sonra İdareye Muvakkatten El Koymuş Bulunmaktadır” haberiyle öğrenmiştir. ${ }^{23}$ Darbenin hemen akabinde Bitlis Valiliği lağvedilmiş ve Bitlis Askeri Valiliği oluşturulmuş ve buraya Garnizon Kumandanı Kurmay Albay Raşit Pasin atanmıştır. Askeri Valilik tarafından darbeyle ilgili olarak 1 Nolu Tebliğ yayınlanmış ve bu tebliğle sokağa çıkma yasağı getirilmiş ve bütün siyasi faaliyetler men edilmiştir. 1 Nolu Tebliğ'in ardından hemen ardından Bitlis Askeri Valiliği'nin tebliğidir başlığıyla daha birçok bildiri yayınlanmıştır. 28 Mayıs 197. tarihinde yayınlanan Nolu Tebliğ ile uyulması gereken kurallar açık bir biçimde ortaya konulmuştur. ${ }^{24}$

Askeri Vali Kurmay Albay Raşit Pasin imzalı olarak yayınlanan 5 Nolu Bildiride şu talimatlar yer almaktadir:25

1. Transit geçen posta arabaları ile hasta arabaları Garnizon Kumandanlı̆̆ından izin almak suretiyle sefere ç1kabilirler.

2. Devlet memurları bugün saat 09.00'dan itibaren vazifelerine başlayacaklardır.

3. Birahane, kahvehane, tiyatro ve sinema gibi umuma açık yerlerin kapalı kalmaları devam edecektir. yasaktır.

4. Beş kişiden fazla toplulukların bir araya gelip konuşmaları ve her türlü siyasi toplantılar

5. Dükkânlar ve içki vermemek suretiyle lokantalar açık bulunacaktır.

6. Şehir halkının asayişinin muhafazasında gösterdikleri sükûn ve anlayışa teşekkür eder, devamını rica ederim (Bitlis Garnizon Kumandanı Kurmay Albay Raşit Pasin).

$\mathrm{Bu}$ maddeler, Bitlis’te sokağa çıkma yasağının ve her türlü siyasi faaliyetin men edildiğini ortaya çıkarmaktadır. Ayrıca, mezkûr bildiriyle vatandaşlara çok büyük yasaklar getirildiği de anlaşılmaktadır. Söz konusu 5 Nolu Bildirinin hemen akabinde çok sayıda yeni tebliğler ilan edilmiştir. Sadece 28 Mayıs'ta 1960 tarihinde birkaç tebliğin aynı gün ilan edildiği görülmektedir. ${ }^{26} \mathrm{Bu}$

21 Yeni Dideban, 27 Mayıs 1960, Say1: 221.

22 Tasviri Efkâr, 28 Mayıs 1960, Say1: 813; Yeni Dideban, 27 May1s 1960, Say1: 221.

23 Yeni Dideban, 28 Mayıs 1960, Sayı: 222.

24 Tasviri Efkâr, 28 Mayıs 1960, Sayı: 813.

25 Yeni Dideban, 28 May1s 1960, Say1: 222.

26 Tasviri Efkâr, 29 Mayıs 1960, Sayı: 814. 
arada, Bitlis'te milletvekilleri olan Nusrettin Barut ile Rıfat Bingöl de Ankara'da gözaltına alınmışlardır. Bitlis'te bazı yöneticiler ve partililer de derdest edilmişlerdir. Bu durum, Bitlis'te darbe etkilerinin ne ölçüde görüldüğünü ortaya çıkarması kapsamında önemli bir durum arz etmektedir. Bitlis'te olan durum, esasında Türkiye'nin genelinde olan durumu da örneklendirmektedir. Zira darbe sonrasında genelde bu durumlar yaşanmaktadır.

Bitlis Askeri Valiliği 30 Haziran 1930 tarihinde 6 Nolu Bildiriyi yayınlamış ve darbe karşısında halkın sağduyulu davrandığını söyleyerek onlara teşekkür etmiştir. Söz konusu bildiriyle Askeri Vali Garnizon Kumandanı Reşit Pasin, halkın göstermiş olduğu anlayışın bölgede huzur ve asayişin sağlanmasına katkısı olduğunu ifade etmiştir. ${ }^{27}$

Daha sonraki süreçte 6 Nolu bir tebliğ daha yayınlanmış ve bu tebliğde bir kısım kişilerin darbeye karşı tepkili olduğu ve darbe karşıtı hareketler içerisinde bulundukları anlaşılmaktadır. $\mathrm{Bu}$ durum da 6 Nolu Tebliğin 1 nolu maddesinde şu şekilde ifade edilmektedir: "Fena niyetli ve menfaatperest şahıslara kulak asılmaması ötede beride gevezelik yaparak emniyet ve huzuru bozacak insanlara kıymet verilmemesi memleketin menfaatti icabıdır. Her vatandaşın huzur ve emniyetle kendiişleriyle meşgul olmalarını rica ederim. Şehir ile köyler arasında fena maksatla gidip gelenlerin dinlenmemesini, aksi takdirde elebaşı olmaya sebebiyet verecek şahisların mesul tutulacağını. Dini ibadetleri propaganda vasıtası yapanları yakından takip etmekteyim. Inanç ve vicdan hürriyeti fena maksatlar maksat edilmemelidir. Muhterem halkın bu hususları nazarı dikkate çekerim ${ }^{28}$ ". İfade edildiği gibi, halk içinde darbeye karşı olanlar vardır ve bu da Garnizon Kumandanlığı tarafından açık bir biçimde bilinmektedir. Buna karşı olarak da kumandanlık tarafından söz konusu tebliğ yayınlanmış ve vatandaşların bu tür işlere kalkışması yasaklanmıştır.

Darbe sonrasında Bitlis ilinde bu gelişmeler yaşanıyorken; Ankara' da gözaltına alınan ve derdest edilen DP'li iki milletvekili olan Nusrettin Barut ile Rıfat Bingöl 12 Haziran 1960 tarihine kadar Genel Kurmay Başkanlığı binasında tutulmuşladır. Bu tarihten itibaren ise DP'li bütün vekiller Genel Kurmay Başkanlığı'ndan alınarak Yassıada'ya sevk edilmişlerdir. Bunlar arasında sonrada gözaltına alınan diğer Bitlisli mebus olan Selahattin İnan da yer almıştır. ${ }^{29}$

Darbe sonrasında Bitlis genelinde çok sayıda yasakların uygulanmaya konulduğu görülmektedir. Bu yasaklar kapsamında 30 Mayıs 1960 itibarıyla Bitlis genelindeki bütün resmi araçların ne sebeple olursa olsun şehir dışına çıkmaları yasaklanmıştır. Bu araçların çıkmaları gerekirse, söz konusu vasitalara Garnizon Kumandanlığı tarafından uygun bulunması durumunda gerekli izinlerin verileceği bildirilmiştir. ${ }^{30} \mathrm{Bu}$ durum, Askeri Valilik tarafından çok sayıda yasağın uygulanmaya konulduğunu ve her şeyin kumandanlığın denetimine alındığını ortaya çıkarmaktadır.

Yukarıda ifade olunduğu üzere 27 Mayıs Askeri Darbesi’nden sonra ülke genelinde birçok yasaklar oluşturulmuş ve bunlar her gün gazete ve radyolar marifetiyle tebliğler halinde halka duyurulmuştur. Bu yasakların başında güvenlik kuvvetleri dışında silah bulundurma ve taşıma yasağı gelmektedir. Söz konusu yasaklamalar ve önlemler bağlamında, Bitlis Askeri Valiliği tarafından 31 Mayıs 1960 tarihinde yayınlanan 41 Nolu Tebliğ ile silahı olan herkesin 10 Haziran 1960 tarihine kadar silahlarını Bitlis Emniyet Müdürlüğüne ve İlçe Jandarma Komutanlıklarına teslim etmeleri istenmiştir. ${ }^{31}$ Yukarıda ifade edildiği gibi, söz konusu yasaklar ülke genelinde uygulanmış

29 Tasvir-i Efkâr, 10 Haziran 1960, Sayı: 823.

30 Yeni Dideban, 31 Mayıs 1960, Sayı: 224; Tasviri Efkâr, 31 Mayıs 1960, Say1: 817.

31 Tasviri Efkâr, 1 Haziran 1960, Sayı: 818. 
ve herkesin bu yasaklara uymaları için de gerekli önlemler alınmıştır.

\section{27 Mayıs 1960 Asker Darbesinin Haziran Ayında Bitlis'teki Durumu}

Bitlis’teki gazetelere göre, 27 Mayıs Askeri Darbesi’ne karşı çıkıp tepkilerde bulunanlar olduğu gibi darbe lehinde gösteriler bulunanlar da olmuştur. Bu bağlamda 1 Haziran 1960 tarihinde Bitlis'te gençler tarafından otobüs, jeep ve kamyonlar bayraklarla donatılmış ve orduyu övücü tezahüratlar yapılmıştır. ${ }^{32}$ Söz konusu gösteriler başta Yeni Dideban ve Yeşil Bitlis gazeteleri olmak üzere bütün yayın organları tarafından övgüyle haber yapılmıştır. Bu durum, gazetelerin yayın politikalarında darbenin ne derecede etkili olduğunu ortaya çıkarmaktadır. Zira bu gazeteler darbeden önce DP iktidarını övücü yazılar yazmaktayken; darbeden hemen sonra eski iktidarı ciddi bir biçimde eleştiren yazılar yazmaya başlamışlardır. Bu durum, gazeteciler üzerindeki baskıyı göstermektedir. Yani yazılanların çoğunda gerçek düşünceler değil, korkuyla yazılmış yazılar olabileceği şeklinde değerlendirilmektedir.

2 Haziran 1960 tarihinde Askeri Valisi Kurmay Albay Raşit Pasin, ildeki gazetecilerle bir araya gelmiş ve darbe sonrası ilde yaşanan gelişmelerle alakalı olarak onlara bilgi vermiştir. Darbenin ilk gününden beri görevde olduğunu bildiren Askeri Vali, il genelinde huzur ve sükûa nun sağladığını ve huzuru bozacak şeylere karşı her türlü önlemi aldığını söylemiştir. Aynı gün Garnizon Kumandanlığı bir tebliğ daha yayınlamış ve 20:00-06:00 olan sokağa çıkma yasağının saatlerini değiştirmiş ve bu saatleri 23.00 ile 03.00 saatleri olacak şekilde yeniden düzenlemiştir. ${ }^{33}$ $\mathrm{Bu}$ durum, darbenin ilk günlerinde uygulanan bazı yasakların darbecilerin kendilerini kabul ettirip güvence altına aldıktan sonra yumuşatıldığını göstermektedir.

Bitlis’te bu gelişmeler yaşanırken; 3. Ordu Komutanlığ 1 tarafından bütün ülkeyi ilgilendiren bir bildirinin yayınlandığı görülmektedir. Bu tebliğgde darbenin neden yapıldığ de kardeşkanının akıtılmasını engellemek amacıyla darbe yapıldığı ifade edilmiştir. Burada dikkat çeken şey ise, Bitlis'te olduğu gibi ülke genelinde de darbeye karşı ciddi bir tepkinin varlığıdır. Yani halkın içinden bazıları darbe karşıtı bir tavır sergilemişlerdir ve bu da 3. Ordunun bildirisinde açık bir biçimde yer almıştır. Bununla ilgili olarak tebliğde şu ifade yer almaktadır: "Maalesef bazı müfrit partili ve bedbaht vatandaşların şahsi ihtiraslarına kapılarak kışkırtıcı konuşmalarda bulunduklart tespit edilmiş ve gereken tedbirler alınmıştır. Bu gibi bozguncu hareketlere katiyen müsaade edilmeyecektir ${ }^{34}$ ". Buradan çok açık bir biçimde görülebileceği çok sayıda DP'liler darbe aleyhinde olmuşlardır ve bu da Bitlis’te olduğu gibi diğer yerlerde de Milli Güvenlik Komitesi’nin raporlarına yansımıştır.

8 Haziran 1960 tarihinde Bitlis Garnizon Komutanlığı tarafından yeni bir tebliğ yayınlanmış ve bu bildiride bazı önemli memurlukların nasıl yürütüleceği karara bağlanmış ve bazı kurumların lağvedildiği belirtilmiştir. Buna göre, Bitlis Belediye Başkanlığı Meclisi, Bitlis Belediye Başkanlığ Encümenliği, Bitlis Valiliği Encümenliği, Bitlis'e bağlı ilçelerin belediye başkanlıkları, encümenlikleri, il özel idare müdürlükleri ile Bitlis genelinde bulunan bütün muhtarlıklar ve ihtiyar heyetlerinin tamamı geçersiz hale getirilmiştir. Akabinde söz konusu görevlerin bazılarına askeri yetkił liler getirilmiş ve bazılarına da askeri yetkililerin uygun gördükleri atanmıştır. Yani, Bitlis’teki bu önemli görevlerin tamamına Askeri Vali Kurmay Albay Raşit Pasin'in talimatlarıyla yeni kişiler

32 Yeni Dideban, 2 Haziran 1960, Say1:226.

33 Dideban, 3 Haziran 1960, Sayı: 621; Tasviri Efkâr, 4 Haziran 1960, Sayı: 821; Yeni Dideban, 3 Haziran 1960, Sayı:227; Yeşil Bitlis, 4 Haziran 1960, Sayı: 2108.

34 Tasviri Efkâr, 1 Haziran 1960, Sayı: 822. 
atanmıştır. Ayrıca Bitlis Belediye Başkanlığı görevi de Askeri Valiliğin himayesine alınmıştır. Bu arada Bitlis'teki çok sayıda muhtar görevden alınmış ve yerlerine Asker Vali ve kaymakamların tespit ve tayin ettiği kişiler atanmıştır. ${ }^{35}$ Söz konusu düzenlemeler ve atamalar, ülke genelinde olł duğu gibi Bitlis’te darbenin ne derecede etkin bir duruma geldiğini ortaya çıkarmaktadır.

Darbe sonrasında Bitlis'teki halkın bir bölümünün darbe karşıtı oldukları ve buna önlem olarak Bitlis Askeri Valiliği'nin önlem amaçlı bazı tebliğler yayınladığı yukarıda ifade edilmişti. Bu bağlamda, Bitlis Askeri Valiliği ve Garnizon Kumandanlığ 1 tarafından yeni bir bildiri daha yayınlanmıştır. Söz konusu bildiride, eski iktidar mensupları tarafından kardeş kavgasına yol açacak hareketler olduğu ve partililerin zararlı faaliyetler içinde olduğu ifade edilmiştir. Bilhassa bunların engellenmesi için mahalli idare amirleri tarafından gerekli önlemlerin de alınacağ bildirilmiştir. ${ }^{36}$ $\mathrm{Bu}$ durum, yukarıda da diğer örneklerde açıklandığı üzere söz konusu darbenin ülke genelinde olduğu gibi Bitlis vilâyetinde de bazı insanlar tarafından istenmediği ve tepkiyle karşılandığı şeklinde değerlendirilmektedir.

Yukarıda izah edildiği üzere, 27 Mayıs Askeri Darbesi’nden sonra Bitlis Valiliğine Garnizon Komutanı olan Kurmay Albay Raşit Pasin atanmış ve mevcut Bitlis Valisi olan Muhsin Gökkaya da görevden alınmıştı. Raşit Pasin'in bu görevi 9 Haziran 1960 tarihine kadar devam etmiştir. 9 Haziran tarihiyle de Bitlis Valiliğine Vefa Poyraz atanmıştır. Bu arada, Bitlis eski Valisi olan Muhsin Gökkaya da Çanakkale Valiliğine tayin edilmiştir. ${ }^{37}$ Vefa Poyraz, 15 Haziran'da Bitlis'e gelerek göreve başlamıştır. Valilik yanında Bitlis Belediye Başkanlığı görevini de üstlenmiştir. ${ }^{38}$ Böylece, adı geçen Valinin bu göreve atanmasıyla beraber Valilik yeniden sivil bir idarenin denetimine geçmiş olarak yorumlanabilir.

Darbeden sonra Milli Birlik Komitesi, 28 Nisan ile 27 Mayıs 1960 arasında geçen süre içerisinde yüzlerce gencin öldürüldükten sonra kamyonlarla mezarlıklara getirilip gizlice gömüldüğünü iddia etmiştir. Bu nedenle de söz konusu gençler "Hürriyet Şehitleri” olarak adlandırılmıştır. Akabinde de darbe sonrası bunlar için törenler düzenlenmiştir. Bu kapsamda, 9 Haziran 1960 tarihinde Bitlis’te de anma törenleri yapılmış ve Hürriyet Şehitleri için Mevlut okutulmuştur. ${ }^{39}$ Söz konusu durum, darbenin insanlar üzerinde ne derecede bir etki gösterdiği ve halkın doğruluğu hiçbir zaman kanıtlanmayan bu tür olayları kabul etmeye mecbur edildiği şeklinde yorumlanmaktadır.

Darbeden sonra Doğu Anadolu Bölgesi’nin bütün yönetimi Milli Birlik Komitesi’nin denetimine alınmış ve Doğu Bölgesi Milli Birlik Komitesi Başkanlığı oluşturarak başkanlığına 3. Ordu Komutanı Korgeneral Danyal Yurdatapan atanmıştır. Merkezi Erzurum'da olan Başkanlık tarafından doğu illerinde incelemeler yapılmıştır. Bu bağlamda, 3. Ordu Komutanı Korgeneral Danyal Yurdatapan 12 Haziran 1960'ta Bitlis'e gelmiş ve burada temaslarda bulunmuştur. Dideban gazetesine göre ziyaretleri sırasında kendisine büyük bir ilgi gösterilmiştir. ${ }^{40}$ Adı geçen gazete, darbeden hemen önce Hükümet yanlısı yayınlarıyla bilinmektedir. Darbeden sonra bu gazetenin darbeyle ilgili olumlu yazılar kaleme alması, darbeden dolayı basın organlarının yayın politikalarını nasıl değiştirdiklerini gözler önüne sermektedir.

Gazetelerin verdiği bilgilere göre, Türkiye'de darbeye karşı aleni olmasa da büyük bir tepki

\footnotetext{
35 Yeni Dideban, 9 Haziran 1960, Say1: 233.

36 Dideban, 10 Haziran 1960, s.628.

37 Yeni Dideban, 10 Haziran 1960, Say1: 229; Tasviri Efkâr, 10 Haziran 1960, Say1: 821.

38 Yeşil Bitlis, 16 Haziran 1960, Sayı: 234; Dideban, 16 Haziran 1960, Sayı: 234.

39 Tasvir-i Efkar, 10 Haziran 1960, Say1: 821.

40 Dideban, 13 Haziran 1960, Say1: 631.
} 
bulunmaktadır. Bunun farkında olan Milli Birlik Komitesi de birtakım önlemler almak zorunda kalmıştır. Bunlardan birisi de Askeri Mahkemelerin etkin bir biçimde faal hale getirilmesidir. Bu kapsamda Bitlis'te Milli İnkılâp Hareketlerine ve Milli Birlik Komitesi emirlerine riayet etmeyen ve menfi propaganda yapan şahıslar hakkında yapılacak tahkikatın askeri mahkemelerce yapılması kararlaştırılmıştır. ${ }^{41}$ Milli Birlik Komitesi'nin Bitlis şubesinin bu kararı, halkın darbeye tepkisini ve bakışını bariz bir biçimde ortaya koymaktadır.

Darbe döneminde ülkenin büyük bir kesiminde olduğu gibi Bitlis ilinde de devletin altın stokunu takviye etmek için alyans, küpe, kolye, bilezik ve ziynet eşyalarını hazineye bağışlamak amacıyla Bitlis'te faaliyetler yürütülmüştür. Vatandaşların bağışladığı altınları kabul etmek üzere Bitlis Askerlik Şubesi Başkanlığı'ndan bir heyet, bağışlanan altınları makbuz karşılığında almıştır. Aynı tarihlerde Bitlis Jandarma Kumandanlığı mensupları olan subay, astsubay, erat ve eşleri tarafindan da 43 adet altın ve yüzük orduya verilmiştir. ${ }^{42}$ Ayrıca, bu olaya katılımı arttırmak gayesiyle Siirt Garnizon Kumandanlığg tarafından bütün bölgeye uçakla bildiriler atılmıştır. ${ }^{43}$

16 Haziran 1960 tarihinde 7. Kolordu Kumandanı General Cemal Tural, Bitlis'e gelerek burada birtakım temaslarda bulunmuştur. Adı geçen kişi Bitlis'e gelmeden önce günlerce bu gezinin duyurusu yapılmış ve bütün vatandaşlardan Valilik önünde toplanarak konuşmaları dinlemeleri istenmiştir. Dideban gazetesine göre, Bitlis halkı ordu mensuplarına çok güvenmekte ve sevmektedir. Bu sevgilerini göstermek için de büyük bir kitlenin alana geldiğini ve hatibi dinlediklerini haber vermiştir. Gazeteye göre, siyasetin tamamen dişında olan bu etkinliğe sadece şehir merkezi değil; ilçe, nahiye ve köylerden de çok sayıda kişi gelerek General'i dinlemek istemişlerdir. ${ }^{44}$ Dideban gazetesi, bu etkinliği şehirde bayram havası adlı başlıkla duyurmuştur. ${ }^{45}$ Söz konusu haber, gazeteler üzerinde darbenin ne derece etkili olduğunu ve gazetecilerin yayın organları üzerinde ne gibi bir etkide bulunduğunu ifşa etmektedir.

27 Mayıs Askeri Darbesi'nden sonra Milli Birlik Komitesi tarafından Bitlis ilinde gözaltına alınmış bulunan eski iktidar mensuplarının suiistimallerini ortaya çıkarmak amacıyla bir komisyon kurulduğu ifade edilmişti. Bu komisyon başta Ankara olmak üzere bütün illerde de faaliyete başlamıştı. İllerdeki söz konusu araştırmaları hızlandırmak amacıyla ayrıca tetkik komisyonları da oluşturulmuştur. Bu arada il ve ilçelerde görev yapan komisyonlarla alakalı olarak yeni bir tüzük de hazırlanmıştır. ${ }^{46}$ Yeşil Bitlis gazetesine göre, söz konusu komisyon Bitlis’te çok aktif olarak yer almıştır.

\section{SONUÇ}

27 Mayıs 1960 askerî müdahalesi, Türkiye’nin çok partili hayata geçişiyle başlayan demokrasi tarihine ağır bir zarar veren ve Türkiye'de darbelerle muhtıraları başlatan bir süreç olmuştur. Nitekim söz konusu askeri darbeyle seçimle ve halkın oylarıyla iktidara gelen partiye son verilmiş ve Türkiye'de demokrasi alanında atılan adımların ciddi bir şekilde durmasına ortam hazırlamıştır. 27 Mayıs 1960 tarihinden sonra da Türkiye'de askeri darbelerle demokrasi süreci bazı tarihlerde akamete yani kesintiye uğramıştır.

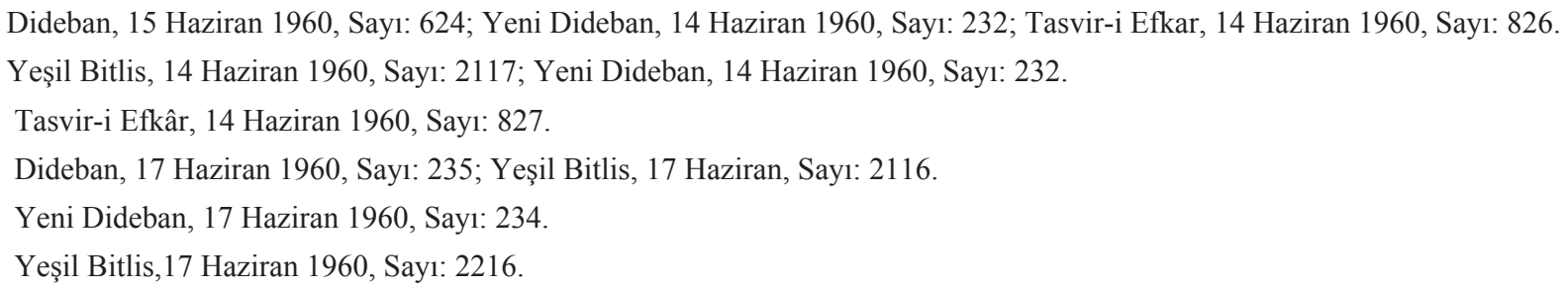


Hem DP iktidarında hem de 27 Mayıs 1960 askeri darbesinin yapıldığı tarihlerde Bitlis basını içinde yer alan Yeşil Bitlis, Dideban, Tasviri Efkâr ve Yeni Dideban adlı gazeteler, 27 Mayıs Askeri darbesi yapıldığında ve yapıldıktan sonra ulusal gazetelerin yaptıkları gibi darbeden yana bir tavır içinde olmuşlar ve bu durumu öven yazılar kaleme almışlardır. Örneğin darbe öncesinde Başbakan Adnan Menderes ve Hükümeti sürekli öven ve yaptıkları çalışmaları beğenen adı geçen gazetelerin Hükümet ile alakalı olarak eleştirel herhangi bir haberleri yoktur. Darbeden hemen bir gün sonra ise bütünüyle farklı bir tutum içine giren gazeteler, eski DP yönetiminden ve partililerden sürekli olarak olumsuz bir şekilde bakmaya başlamışlardır. Bu da, askeri yönetimlerin basın yayın organları üzerinde ne derecede etki gösterdiklerini net bir biçimde ortaya çıkarmaktadır.

Günümüzde etkileri ve durumu hala tartışılan 27 Mayıs Askeri Darbesi, ülke genelinde oldu$\breve{g u}$ gibi Bitlis ilinde de hem demokrasinin hem de insan hak ve özgürlükleri açısından ciddi zararları olmuştur. Bilhassa Bitlis vilâyetinde 10 yıl boyunca yapılan başta milletvekili genel seçimleri olmak üzere belediye meclisi seçimleri, il genel meclisi seçimleri ve muhtarlık seçimlerinin tamamını kazanan ve adı geçen 10 yıllık süre içerisinde Bitlis tarihinde mühim izler bırakan DP'nin iktidarının askeri darbeyle sonlandırılması, halk nazarında ciddi etkiler bırakmıştır. Bu durum, metin içinde açıkça gösterildiği gibi devrin basınında aleni bir biçimde gözlemlenebilmektedir.

\section{KAYNAKLAR}

\section{Araştırma ve İnceleme Eserleri}

AHMAD, Feroz, Modern Türkiye’nin Oluşumu, 11. Baskı, Çev. Yavuz Alogan, İstanbul: Kaynak Yayınlar1, 2012.

ARSLAN, Zühtü , Türk Parlamento Tarihi TBMM- XI. Dönem (1957-1960), III. Cilt, Ankara: Türkiye Büyük Millet Meclisi Yayınları, 2013..

BULUT, Sedef, Üçüncü Dönem Demokrat Parti İktidarı (197•-190v): Siyasi Baskılar ve Tahkikat Komisyonu, Akademik Bakış Dergisi, 2/4 (2009), s.125-145.

ÇAVDAR, Tevfik, Türkiye’nin Demokrasi Tarihi (1839-1950), 3. Bask1, İstanbul: İmge Kitabevi, 2013.

ERTEM, Barış, Siyasal Bir Muhalefet Denemesi Olarak Serbest Cumhuriyet Fırkası, ODTÜ Sosyal Bilimler Enstitüsü Sosyal Bilimler Araştırmaları Dergisi, 2010 1(2), ss.71-92.

GÜNDOĞDU, Şükran, "Bitlis ve Bitlis Halkevi”, (Yayınlanmamış Yüksek Lisans Tezi), Yüzüncü Yıl Van Üniversitesi Sosyal Bilimler Enstitüsü, Van, 2013.

KARPAT, Kemal H., Türk Demokrasi Tarihi (Sosyal, Kültürel, Ekonomik Temeller), (Ed. Nevin Akbıyık), , İstanbul: Timaş Yayınları, 2010.

LEWİS, Bernard, Modern Türkiye’nin Doğuşu, 5. Baskı, (Çev. Prof. Dr. Metin Kıratlı), Ankara: Türk Tarih Kurumu Yayınları, 1993.

ÖZDAĞ, Ümit, Menderes Döneminde Ordu-Siyaset İlişkileri ve 27 Mayıs İhtilali, İstanbul: Boyut Yayın Grubu, ז... .

ÖZTÜRK, Kazım, Türk Parlamento Tarihi, TBMM-IX. Dönem (1950-1954), VII. Cilt, Ankara: Türkiye Büyük Millet Meclisi Yayınları, 1999.

ÖZTÜRK, Kazım, Türk Parlamento Tarihi TBMM- X. Dönem (1954-1957), III. Cilt, Ankara: Türkiye Büyük Millet Meclisi Yayınları, 2010, s.130-131. 
ŞAHIN, Enis ve TUNÇ, Bilal, Demokrat Parti'nin Kuruluş Süreci ve DP-CHP Siyasi Mücadelesi (1945-1947), Sosyal ve Kültürel Araşttrmalar Dergisi, 1 /2 (2015), ss.31-69.

TAŞKIRAN, Cemalettin, Atatürk Döneminde Demokrasi Denemeleri (1925-1930), Ankara Üniversitesi Türk İnk1lâp Enstitüsü Atatürk Yolu Dergisi, 4/14 (1994), ss.255.260.

TOPÇU, İlyas ve ORAN ASLAN, Nebahat, Kars'ta 1950-1954-1957 Milletvekili Seçimleri ve Demokrat Parti, Türkiyat Araştırmaları Enstitüsü Dergisi, 58 (2007), ss.389-407.

TURAN, Murat, "Cumhuriyet Halk Partisi'nin Doğu Örgütlenmesi”, (Yayınlanmamış Yüksek Lisans Tezi), Dokuz Eylül Üniversitesi Sosyal Bilimler Enstitüsü, İzmir, 2010.

ZÜRCHER, Erik Jan, Modernleşen Türkiye'nin Tarihi, (Çev. Yasemin Saner Gönen), 7. Baskı, İstanbul: İletişim Yayınları, 2000.

Yıldönümünde 27 Mayıs'1 Hatırlatmak, Türkiye Çalışmaları Grubu, Ankara: SDE Yayınları, 2010.

\section{Gazeteler}

Yeni Dideban, 27 Mayıs 1960, Say1: 221.

Tasviri Efkâr, 28 Mayıs 1960, Sayı: 813.

Yeni Dideban, 28 Mayıs 1960, Say1: 222.

Tasviri Efkâr, 29 Mayıs 1960, Say1: 814.

Yeşil Bitlis, 30 Mayıs 1960, Sayı:2104.

Yeni Dideban, 30 Mayıs 1960, Sayı:223.

Yeni Dideban, 31 Mayıs 1960, Say1: 224.

Tasviri Efkâr, 31 Mayıs 1960, Sayı: 817.

Tasviri Efkâr, 1 Haziran 1960, Sayı: 818.

Yeni Dideban, 2 Haziran 1960, Say1:226.

Dideban, 3 Haziran 1960, Say1: 621.

Tasviri Efkâr, 4 Haziran 1960, Say1: 821.

Yeni Dideban, 3 Haziran 1960, Sayı:227.

Yeşil Bitlis, 4 Haziran 1960, Sayı: 2108.

Tasviri Efkâr, 1 Haziran 1960, Sayı: 822.

Yeni Dideban, 9 Haziran 1960, Say1: 233.

Dideban, 10 Haziran 1960, s.628.

Yeni Dideban, 10 Haziran 1960, Sayı: 229.

Tasviri Efkâr, 10 Haziran 1960, Say1: 821.

Yeşil Bitlis, 16 Haziran 1960, Sayı: 234.

Dideban, 16 Haziran 1960, Say1: 234.

Tasvir-i Efkâr, 10 Haziran 1960, Sayı: 821.

Dideban, 13 Haziran 1960, Say1: 631. 
Tasvir-i Efkâr, 10 Haziran 1960, Sayı: 823.

Dideban, 15 Haziran 1960, Say1: 624.

Yeni Dideban, 14 Haziran 1960, Sayi: 232.

Tasvir-i Efkâr, 14 Haziran 1960, Say1: 826.

Yeşil Bitlis, 14 Haziran 1960, Say1: 2117.

Yeni Dideban, 14 Haziran 1960, Say1: 232.

Tasvir-i Efkâr, 14 Haziran 1960, Sayı: 827.

Dideban, 17 Haziran 1960, Say1:235.

Dideban, 17 Haziran 1960, Say1: 235.

Yeşil Bitlis, 17 Haziran 1960, Sayı: 2116.

Yeni Dideban, 17 Haziran 1960, Say1: 234.

Yeşil Bitlis, 17 Haziran 1960, Sayı: 2216.

Tasviri Efkâr, 18 Haziran 1960, Say1: 830. 